\title{
Contribution of Benthic Processes to the Growth of Ooids on a Low-Energy Shore in Cat Island, The Bahamas
}

\author{
Giulio Mariotti ${ }^{1,2,3}$, Sara B. Pruss ${ }^{4, *}$, Roger E. Summons ${ }^{3}$, Sharon A. Newman ${ }^{3,5}$ and \\ Tanja Bosak ${ }^{3}$ \\ 1 Department of Oceanography and Coastal Sciences, Louisiana State University, \\ Baton Rouge, LA 70803, USA; giulio.mariotti@gmail.com \\ 2 Center for Computation and Technology, Louisiana State University, Baton Rouge, LA 70803, USA \\ 3 Department of Earth, Atmospheric and Planetary Sciences, Massachusetts Institute of Technology, \\ Cambridge, MA 02139, USA; rsummons@mit.edu (R.E.S.); sharon.newman4@gmail.com (S.A.N.); \\ tbosak@mit.edu (T.B.) \\ 4 Department of Geosciences, Smith College, Northampton, MA 01063, USA \\ 5 California Institute of Technology, Division of Geologic and Planetary Sciences, Pasadena, CA 91125, USA \\ * Correspondence: spruss@smith.edu
}

Received: 1 May 2018; Accepted: 11 June 2018; Published: 14 June 2018

\begin{abstract}
Ooids are typically found in frequently reworked coastal sediments, and are thought to accrete by inorganic chemical precipitation around moving grains. The high organic content and the presence of biosignatures, however, suggest that ooids interact with benthic microbial communities. Here, we investigate the role of benthic processes on ooid growth on a leeward shore of Cat Island, The Bahamas. Polished ooids are present in the surf zone, whereas dull ooids and grapestones are present in microbially colonized sediments seaward of the surf zone. Wave hydrodynamics and sediment transport modeling suggest that microbially colonized sediments are mobilized at monthly time scales. We propose a new conceptual model for both ooids and grapestone. Ooids rest and accrete in the area covered by microbial mats, but are periodically transported to the surf zone where wave abrasion polishes them within days. Ooids are then transported back to microbially colonized areas where the accretion cycle resumes. Ooids too large to be transported become trapped outside the surf zone, exit the "conveyor belt" and become grapestones. The benthic growth mechanism predicts petrographic characteristics that match observations: successive ooid laminae do not thin outward, laminae exhibit irregularities, and some ooids include multiple nuclei.
\end{abstract}

Keywords: Pigeon Cay; grapestone; abrasion; carbonate precipitation; microbial mat

\section{Introduction}

Carbonate platforms of all ages contain ooids, which are spheroidal to ovoid, concentrically laminated carbonate grains. Although these grains are ubiquitous in the rock record, questions of where and how they form and what biological and abiotic processes they record are still debated. Ooids are typically found in shallow, tropical, high energy environments. These conditions are thought to promote the chemical precipitation of small calcium carbonate crystals around suspended grains, a process known as the "suspended growth mechanism" [1-4]. Some experiments support the interpretation of ooids as chemical precipitates in suspension: ooid-like particles have been successfully recreated in the laboratory in agitated seawater that was supersaturated with respect to calcium carbonate $[5,6]$. The mineralogy and the stable $\mathrm{C}$ and $\mathrm{O}$ isotope signatures of carbonate in modern marine ooids also suggest that these grains record the composition of surface seawater $[3,7]$. 
Therefore, models of ooid formation either assume that microbial processes do not substantially contribute to ooid growth [8,9], or that microbial processes are responsible for the production of most ooid carbonate [10,11].

Although laboratory-based studies demonstrated the potential for the inorganic precipitation of carbonate around suspended ooids, the microbial contribution to ooid growth in marine environments remains debated. Notably, carbonate in modern marine ooids incorporates one to three weight percent of organic material $[5,12-18]$. If carbonate precipitates around ooids while they are in suspension within frequently mobilized sediments [18-20], i.e., under conditions that preclude the growth in benthic microbial mats [21-23], then questions remain regarding where and when ooids accumulate organic matter and molecular fingerprints of microbial colonization.

Isotopic values sampled by marine biogenic carbonates neither conclusively support nor refute a contribution from biological processes to the formation of ooid carbonate. The compositions of $C$ and $\mathrm{O}$ isotopes in the precipitated minerals of marine stromatolites that have been unambiguously categorized as microbial carbonates [24] can exhibit enrichments in ${ }^{13} \mathrm{C}$, suggestive of photosynthetic microbial activity or methanogenesis in the surface waters $[25,26]$, depletions in ${ }^{13} \mathrm{C}$ due to organic degradation within the loci of carbonate precipitation [27], or combinations thereof. Carbon isotope values of ooids are also within the range expected for the equilibrium precipitation of carbonate in seawater and some biogenic carbonates such as the aragonite needles precipitated by green algae that are abundant in the Bahamas [28]. Thus, a variety of biogenic carbonates can have isotopic signatures that are identical to those attributed to the equilibrium precipitation of carbonate minerals in seawater.

A possible clue to the origin of some ooid carbonate comes from grapestones-coated, dull, irregularly shaped composite grains that commonly contain ooids. Grapestones are found in areas that are less frequently reworked and/or colonized by microbes and are thus interpreted to be products of carbonate precipitation, grain growth and the accumulation of organic matter within microbially colonized sediments [29-34]. Herein we will refer to this mechanism as "benthic growth", independent of the actual organisms or biochemical pathways responsible for it.

The idea that benthic growth might be involved in ooid formation is supported by findings of dull, coated and encrusted ooids within areas covered by microbial mats in tidal lagoons [35] and tidal shoals [36]. Another example is the "oolitic facies" described by Purdy [29] in the Great Bahamas Bank, a facies of about $3000 \mathrm{~km}^{2}$ covered by a thin brownish-colored organic film. Similarly, "oolitic facies" composed of ooids that formed in quiet and presumably microbially-covered sediments have been described in the geologic record [37].

A common benthic growth mechanism for ooids, oncoids and grapestones was suggested by Fabricius [31], who noticed that "in fossil marine oolites one frequently observes that ooids exceeding a certain grain-size lose their sphericity, and assume a shape more like an 'oncoid'; similarly, organic fabrics begin to appear. If one accepts the phytogenetic origin of marine ooids, it seems more plausible to accept a transition between ooids and oncoids, and also from oncoids to spherical stromatolites". A recent study strengthened the case for a common origin for grapestone and ooid carbonate by comparing the organic signals bound within the carbonate in grapestones, dull ooids and polished ooids along an onshore-offshore transect and finding nearly identical lipids in all these grains [38]. These lipids underscored the contribution of benthic microbes to the organic matter in ooids, preserved as signals of extensive, and possibly anaerobic, heterotrophic degradation that accompanies or precedes the accretion of carbonate around all grain types [38]. At the same time, none of these grains contained organic matter similar to the organic matter from the water column [38].

Two different models can explain the acquisition of organic signatures from microbial communities by ooids: (1) Organic matter coats ooids that rest in microbially colonized sediments, but ooid carbonate precipitates while the ooids are suspended; (2) At least some ooid carbonate precipitates and binds organic matter while ooids rest within microbial communities. In the first model, the inclusion of organic matter is accidental and unrelated to the growth mechanism [5,7]. In the second model, ooids grow in a manner similar to grapestones, i.e., within benthic microbial mats, but are 
periodically suspended and abraded. In any case, if organic signals of benthic microbial activity are to be incorporated into ooids, those ooids must spend part of their growth cycle within benthic microbial communities.

Ooids in the field are particularly abundant in high energy areas that do not contain abundant microbial biomass. How can ooids grow within microbial communities if they concentrate in areas devoid of microbial mats? Transport between these different areas by tidal currents and waves offers a potential solution to this contradiction [18], particularly if the transport of individual ooids between these different environments (e.g., the crest and the trough of a sand bar), occurs on time scales shorter than the time scale for ooid growth, which is on the order of hundreds of years or even millennia $[1,7,8,36,39]$. As such, it is plausible that individual ooids repeatedly sample areas with different energies during their life span.

Here, we investigate the potential for episodes of benthic ooid growth. A previous study characterized carbonate grains and carbonate-bound organic biomarkers in the same environment, a modern ooid shore in Pigeon Cay on Cat Island, The Bahamas [38]. The current study analyzes grain size, morphology and petrography, investigates the distribution of microbial mats, and uses a numerical model to characterize sediment transport and sorting across the shore. These results are then used to infer the contribution of hydro-sedimentary conditions of the study site to benthic and suspended growth mechanisms. The predictions of both growth models for the petrography of ooids are compared to the observations in Pigeon Cay and other ooid-rich environments. Finally, we propose directions to further test the two growth models by investigating ooids from different geological ages as well as various locations in the Modern.

\section{Materials and Methods}

\subsection{Study Site}

Cat Island is a $\sim 1 \mathrm{~km}$ wide and $\sim 70 \mathrm{~km}$ long NNW-SSE trending island located between the North Atlantic Ocean to the East and Exuma Sound to the West (Figure 1). A $\sim 10 \mathrm{~km}$ wide carbonate platform is located west of Cat Island. This platform has a $\sim 4 \mathrm{~m}$ thick sediment cover [40], and its elevation gradually slopes westward to 20-30 m water at the shelf break. There, the platform drops into the $\sim 1 \mathrm{~km}$ deep, $\sim 70 \mathrm{~km}$ wide, Exuma Sound without an intervening barrier rim [40].

Most winds come from the North-East (Figure 1a). As such, the westerly platform of Cat Island is relatively quiet, characterized by a wave height that is less than $\sim 0.2 \mathrm{~m}$, except when westerly winds generate swells that are a few meters high [40]. Pigeon Cay, an ooid-rich shore on the leeward side of the island, is exposed to waves originating from a sector between $160^{\circ}$ and $280^{\circ}$ north (Figure 1). Time series of the hourly measurements of wind speed at the NOAA station SPGF1-Settlement Point, GBI, Bahamas-from 1998 to 2013 indicates that wind coming from this sector occurs $\sim 21 \%$ of the time (Figure 1a).

Our study focused on a $150 \mathrm{~m}$ long transect perpendicular to the SW-facing shore in Pigeon Cay (Figure 1c). Contrary to the more commonly studied ooid shoals $[20,41]$, the study area had negligible tidal currents. 

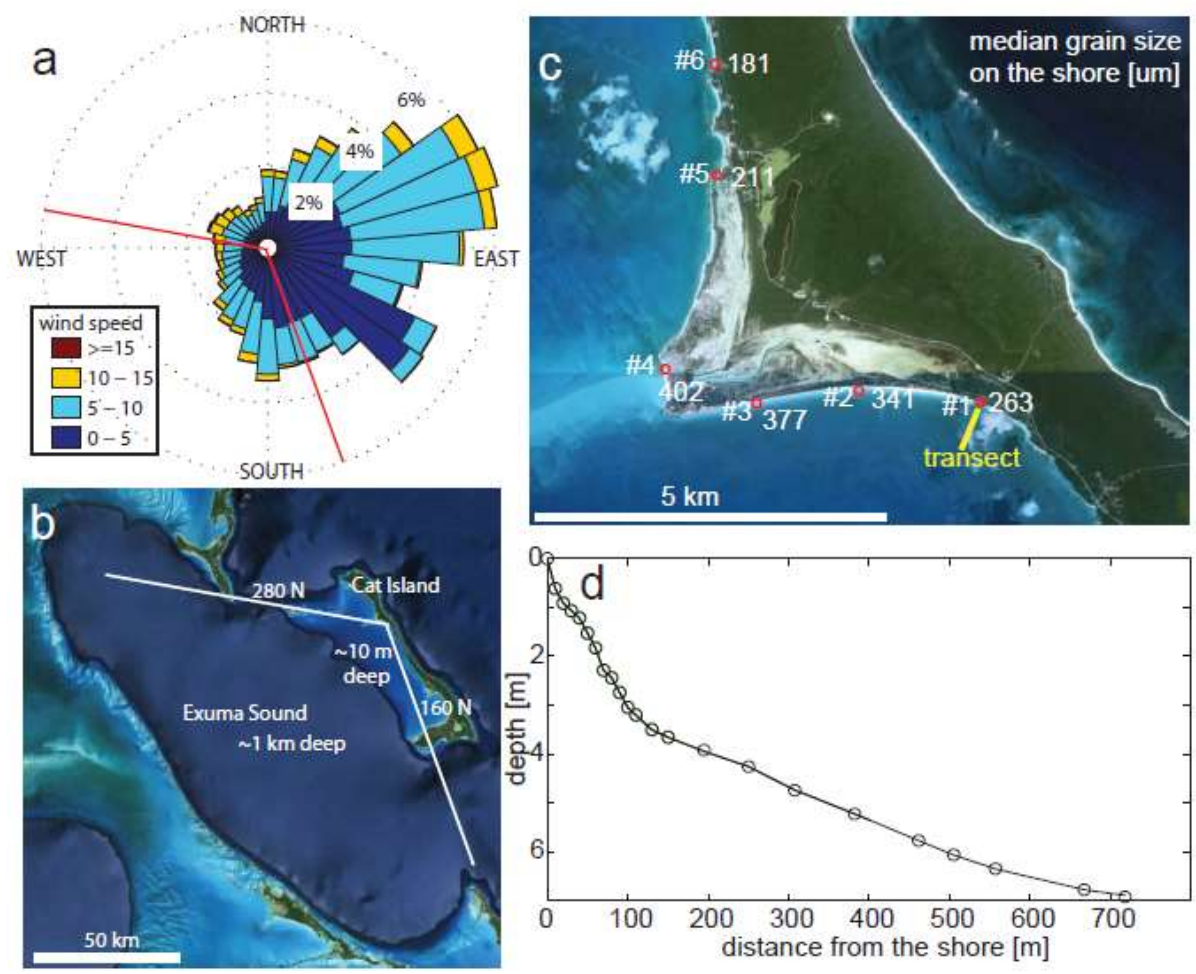

Figure 1. Geographic and environmental characterization of the study site. (a) Wind rose from a station $\sim 400 \mathrm{~km} \mathrm{~N}-\mathrm{W}$ of the study site, representative of the large-scale wind patterns in The Bahamas region. (b) Image of Cat Island and its shallow shelf. The lines identify the wave exposure of the study site, Pigeon Cay. Only winds blowing from the sector approximately between $160^{\circ}$ and $280^{\circ} \mathrm{N}$ generate waves that impact the shore. (c) Detail of Pigeon Cay in Cat Island. Red dots indicate sampling sites along the beach, yellow line indicates the cross-shore transect. Numbers near the dots show the median grain size $[\mu \mathrm{m}]$ at each sampled locality. Images from GoogleEarth (NASA, DigitalGlobe 4/28/2013). (d) Depths along an $800 \mathrm{~m}$ long transect. The depths were measured using a rope from a kayak with a $10 \%$ error in depth and position.

\subsection{Field Measurements and Petrographic Analyses}

Sediment samples were collected on 20 May 2014 along the transect (Figure 1c): nine surface grabs ( $1 \mathrm{~kg}$ each) sampled the top $5 \mathrm{~cm}$ of the sediment, and three samples were taken as $70 \mathrm{~cm}$ long cores using a $1 \mathrm{~m}$ long push-pull coring device. Surface samples were also collected at an additional five locations along the shoreline (Figure 1).

Sediments were dry sieved and divided into eight size classes; grain size distribution was determined using the Gradistat software [42]. Grain shape parameters were measured by taking microphotographs of the particles that rested on a flat surface, using about 100 grains from each location. Photographs had 1600 by 1200 pixels, with a pixel size of $10 \mu \mathrm{m}$. Images were automatically analyzed using algorithms for binary conversion and cluster identification [43]. Two parameters were calculated: the degree of sphericity and the aspect ratio. Degree of sphericity is defined as the ratio between the perimeter of a circle of the same area as the projected surface of the particle and the actual perimeter of the projected surface of the particle [44]. This method was modified to account for the two-dimensionality of the measurement. The aspect ratio is defined as the ratio between the major and minor axes of the projected surface of the particle. For each location and size class the relative amount of ooids and composite grains (defined as those particles with more than one nucleus) was determined by examining thin sections, each containing between 20 and 100 grains.

For SEM imaging and EDX analysis, ooids were rinsed three times with double distilled water and exposed to an ethanol-water drying series $(30 \%, 50 \%, 70 \%, 80 \%, 90 \%, 100 \%, 100 \%)$ in seven 
successive 20 min steps. Samples were then attached to carbon tape and coated with gold and palladium (Whitehead Institute, Massachusetts Institute of Technology). Samples were imaged on a SUPRA 55VP scanning electron microscope with an energy dispersive X-Ray spectrometer at $10 \mathrm{kV}$ (Zeiss International, Oberkochen, Germany) at the Center for Nanoscale Systems, Harvard University, Cambridge, MA, USA.

\subsection{Grain Erosion Experiments}

Triplicates of three sediment size fractions (125-250, 250-500 and 500-1000 $\mu \mathrm{m}$ ) with $10 \mathrm{~g}$ of sediment each from five locations along the transect were abraded in the laboratory for one day. The grains were placed in cylindrical plastic jars (6.8 cm tall and wide, BioExpress, Kaysville, UT, USA) that contained $90 \mathrm{~mL}$ of seawater. The jars were then subjected to the horizontal orbital motion with an excursion of $3 \mathrm{~mm}$ and a frequency of $5 \mathrm{~s}^{-1}$. The amount of abraded carbonate mud was determined by spectrophotometric measurements of water turbidity. These measurements were calibrated using solutions with known concentrations (in $\mathrm{g} / \mathrm{L}$ ) of suspended calcium carbonate powder.

\subsection{Hydro-Morphodynamic Model}

The hydro-morphodynamic model Delft3D [45], a commercial software that solves the depth-averaged shallow water equations, was used to simulate the hydrodynamics, sediment transport, grain sorting and morphological evolution of the shore and shelf facing Pigeon Cay. The model uses a Chezy friction factor equal to $45 \mathrm{~m}^{1 / 2} / \mathrm{s}$, appropriate for sand ripples [46] and a horizontal eddy viscosity and diffusivity equal to $0.01 \mathrm{~m} / \mathrm{s}$ [47]. The model was coupled with the wind-wave model SWAN [48] that solves the wave action balance. The wave model includes wind growth [49], whitecapping [50], bed friction [51], wave braking [52] and quadruplet wave interactions [53]. Sediment transport was calculated using a formulation [54] that accounts for the two-way interactions between waves and currents, differentiates between bed and suspended load and explicitly includes onshore transport by wave asymmetry and downslope transport by gravity [54,55].

The model reproduced an idealized $100 \mathrm{~km}$ long transect perpendicular to the coastline. The Exuma Sound was schematized as a $90 \mathrm{~km}$ long and $1 \mathrm{~km}$ deep basin, followed by a $9.2 \mathrm{~km}$ wide shelf with a linearly decreasing depth from $30 \mathrm{~m}$ at the shelf break to $8 \mathrm{~m}$ close to the shore. The last $800 \mathrm{~m}$ of the transect had a slope of 0.01 (i.e., the water depth $800 \mathrm{~m}$ from the shore was $8 \mathrm{~m}$ ). Two classes of sediments were simulated: a fine one $(250 \mu \mathrm{m})$, representative of ooids, and a coarse one $(1000 \mu \mathrm{m})$, representative of larger grains such as grapestones. The initial grain size distribution was uniform in space and had equal volume fractions of fine and coarse material. The relative amount of the two types of grains changed in space and time as a result of sediment transport and sorting and was used as a proxy for the median grain size along the profile.

The model was forced with a synthetic time series of wind speed that was generated by randomly choosing hourly wind speeds and directions from the measured time series. Winds blowing from outside the exposure sector (Figure 1) do not create any wave activity near the shore and were not simulated in the interest of computational efficiency. Great diurnal tidal range in the shelf of Cat Island is about $1 \mathrm{~m}$ (NOAA station TEC4629, The Bight, Cat Island). This tidal variability and its effects on sediment transport were neglected in the model. A multiplicative morphological factor equal to 50 was used to decrease the computational time [56].

\subsection{Modeling Microbial Colonization of Sediments}

The age of the microbial cover was calculated by a simple model which assumes that microbial mats are destroyed when the hourly bed shear stress exceeds a critical value, and that microbes actively colonize the benthos when the shear stress drops below a critical value [57]. The critical value for erosion was set equal to $1 \mathrm{~Pa}$ to account for the presence of very coarse sand and the stabilizing influence of microbial mats [22]. The frequency distribution of microbial mat ages was computed at 
each location along the transect using the same wind speed time series that generated the bed profile and the predicted wave-induced bed shear stress.

\section{Results}

\subsection{Field Data and Petrographic Analyses}

The shore profile in Pigeon Cay is concave up, with a break in slope at a depth of about $4 \mathrm{~m}$ that occurs at a distance of about $150 \mathrm{~m}$ from the beach (Figure 2a). In the surf zone, here defined as the region between the shoreline and the zone where the water depth reaches $2.5 \mathrm{~m}$, sediments are loose, lacking either cohesion or a visible microbial cover (Figures $2 \mathrm{c}$ and $3 \mathrm{a}$ ). Thin, mm-thick, fluffy microbial mats become more widespread at depths larger than about $2.5 \mathrm{~m}$ (Figures 2c and 3b) [38]. Ripples in these microbially colonized areas provide evidence of intermittent sediment reworking (Figure 3b). Where the microbial cover is eroded, sharp, overhanging edges around the eroded areas attest to the stabilization and cohesion of surface sediment.

Grain size fines seaward, from a median diameter of $263 \mu \mathrm{m}$ at the shoreline to a median diameter of $185 \mu \mathrm{m}$ at a depth of about $2.5 \mathrm{~m}$, about $80 \mathrm{~m}$ from the shoreline (Figure $2 \mathrm{~b}$ ). Further offshore, the grains become coarser and poorly sorted and attain a median size of $683 \mu \mathrm{m}$ about $150 \mathrm{~m}$ away from the shoreline (Figure 2). At each of the three cored locations, the median grain sizes at 60-70 cm depth and on the surface are similar (Figure 2). Thus, at least the top $70 \mathrm{~cm}$ of the bed are well mixed in terms of sediment size. Median grain size at the shoreline increases toward the headland, reaches a maximum of $402 \mu \mathrm{m}$ at the outermost point of the headland (point \#4 in Figure 1c) and then decreases away from the headland.

At all surface locations sampled along the $150 \mathrm{~m}$ transect, ooids constitute $\sim 70 \%$ of all grains in the size range $125-250 \mu \mathrm{m}, 50 \%$ in the size range $250-500 \mu \mathrm{m}$, and $0 \%$ in the size range greater than $500 \mu \mathrm{m}$. Grapestones account for the remaining grains in each size range (Figure 4c) and skeletal material contributes less than $1 \%$ of grains in any size fraction at this location on Cat Island. For all locations along the transect the degree of grain sphericity decreases and the aspect ratio increases with the increasing grain size (Figure $4 a, b$ ).
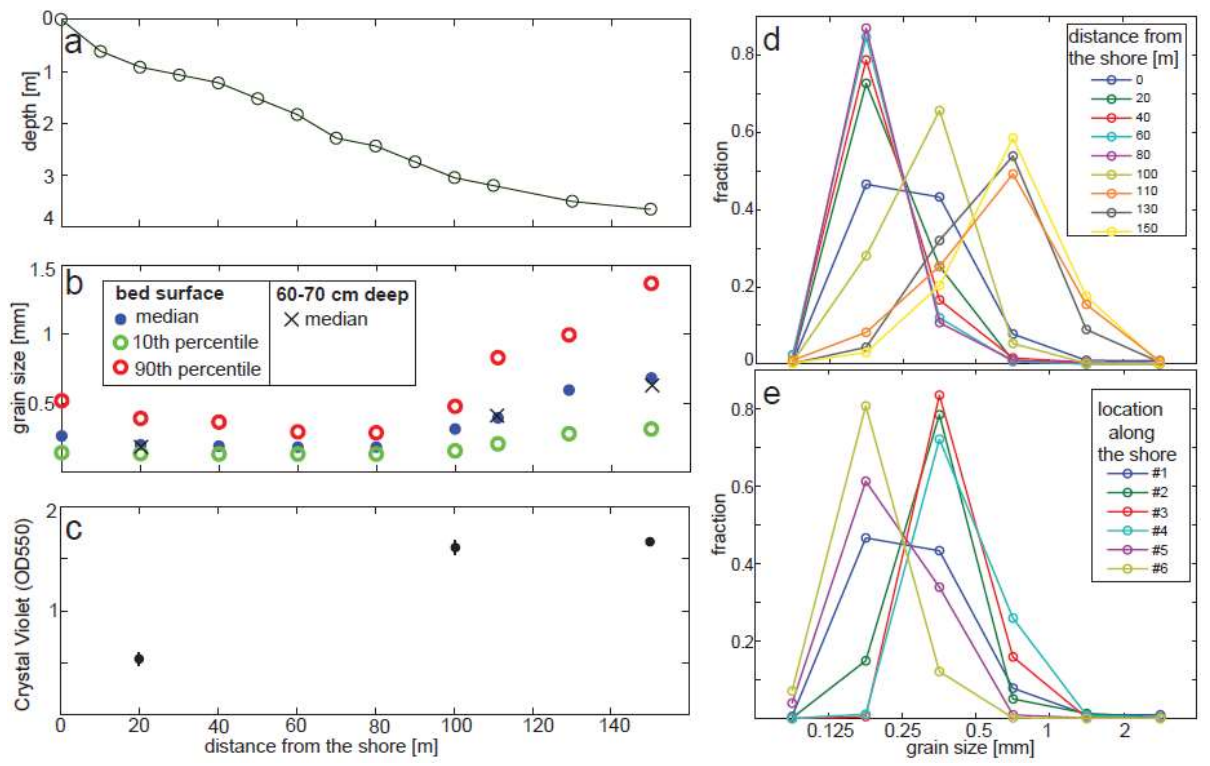

Figure 2. Bed and sediment characteristics in Pigeon Cay. (a) Detail of the bed profile close to the shore. (b) Median, 90th and 10th percentile grain size along the transect, on the bed surface and $\sim 65 \mathrm{~cm}$ below the bed surface at three locations along the transect. (c) Biomass of microbial mats estimated by the crystal violet assay [38] (see Figure 3 for visual comparison). (d,e) Grain size distribution at different locations along the transect and along the shore (see Figure 1). 


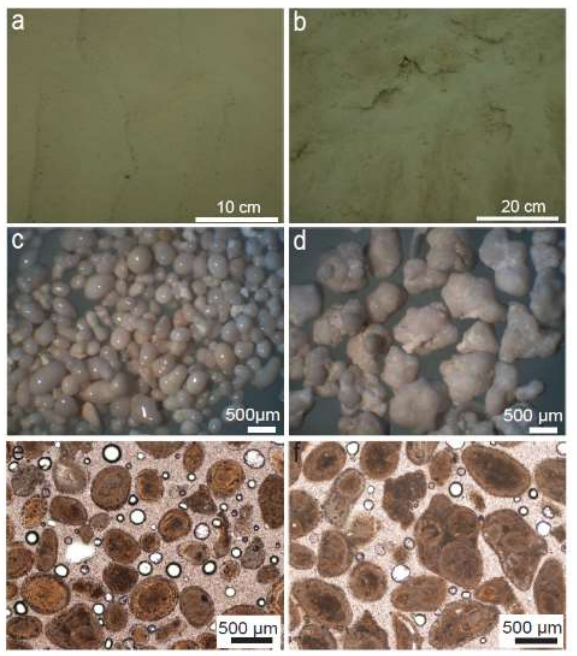

Figure 3. Photographs of the seafloor in Pigeon Cay and photomicrographs of ooids and grapestones. (a) Photograph of barren ripples at a distance of $20 \mathrm{~m}$ from the shore. (b) Photograph of microbially covered and encrusted ripples at a distance of $150 \mathrm{~m}$ from the shore. (c-f) Photomicrographs of grains from different locations along the transect: rounded polished ooids sampled $20 \mathrm{~m}$ from the shore (c,e), irregular dull grapestones collected $150 \mathrm{~m}$ from the shore $(\mathbf{d}, \mathbf{f})$.
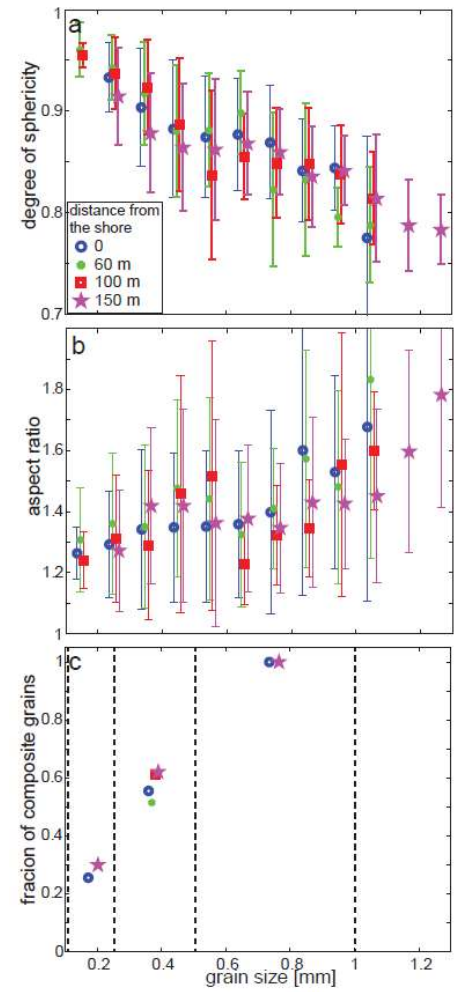

Figure 4. Petrographic characterization of grains at different locations along the transect. (a) Degree of sphericity (the ratio between the perimeter of a circle of the same area as the particle and the actual perimeter of the particle). (b) Aspect ratio (the ratio between the major and minor axis of the particle). Error bars indicate \pm one standard deviation. For each grain size fraction, the two-sample Smirnov-Kolmogorov test confirmed that samples from different locations were drawn from the same distribution $(p<0.05)$. (c) Fraction of composite grains (number of grains that are composite divided by the total number of grains) measured at different locations along the transect. Colored symbols in all panels mark the same locations as shown in the legend of panel a. 
Grains from the surf zone area are polished (Figure 3c), but all grains collected outside the surf zone, where a visible mat cover is present, are dull (Figure 3d). This dullness arises from the presence of microcrystalline and sub-micrometer size carbonate crystals on the grain surfaces (Figure $5 \mathrm{a}, \mathrm{b}$ ).
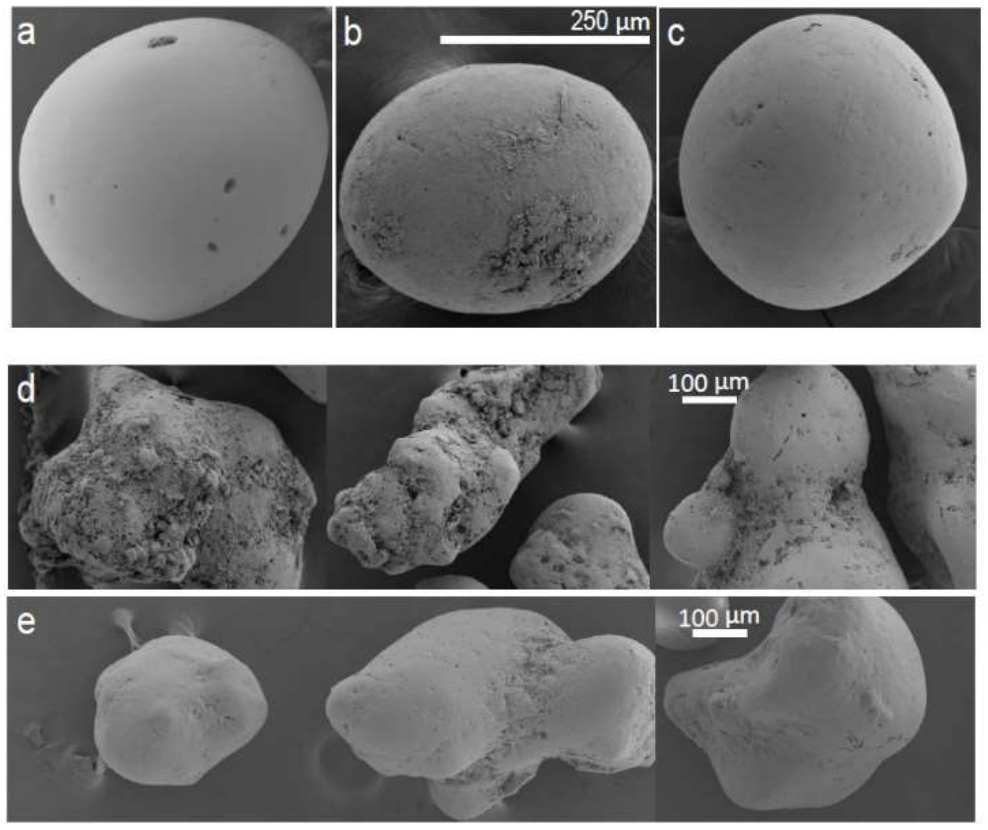

Figure 5. Representative SEM images of ooids in the $250-500 \mu \mathrm{m}$ diameter range from two locations along the transect. (a) Ooids from the barren area at a distance of $20 \mathrm{~m}$ from the shore have a smooth and polished surface. (b) Ooids from the microbially covered area at a distance of $100 \mathrm{~m}$ from the shore have an irregular surface due to the presence of microcrystalline carbonate. (c) Representative image of ooids from the same area as in (b), but after $24 \mathrm{~h}$ of erosion in the laboratory. (d,e) Representative images of grapestones collected at $150 \mathrm{~m}$ from the shore before (d) and after (e) laboratory abrasion.

Laboratory abrasion experiments were performed to determine how grains from different areas change due to abrasion and how fast these changes occur (Figure 6). Mechanical abrasion removed the microcrystalline surface irregularities and polished the dull grains from the microbially covered areas in just one day (Figure 5c). Larger grains abraded more slowly than smaller ones: grains in the $500-1000 \mu \mathrm{m}$ range were composed entirely of grapestones and lost about $0.2 \%$ of mass per day. In contrast, grains in the 125-500 $\mu \mathrm{m}$ range were composed of both ooids and grapestones and lost about $0.4 \%$ of mass per day (Figure 6). Dull grains also abraded faster than the polished grains: polished grains from the barren area lost $0.05 \%$ of mass per day, regardless of the initial grain size. 


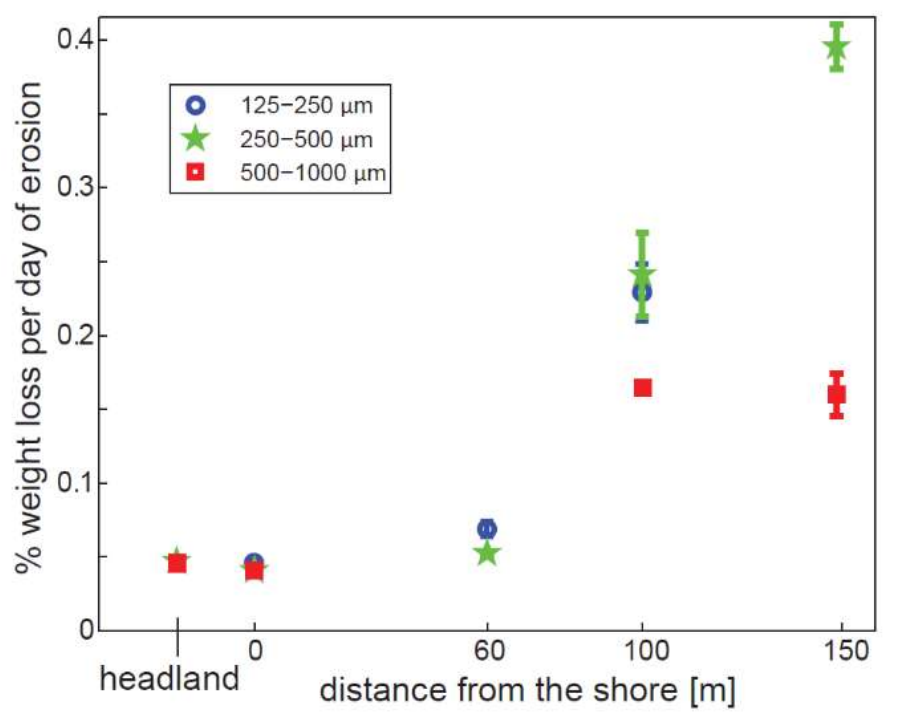

Figure 6. Grain erosion experiments. Mass abraded from samples taken at different locations along the transect and at the headland (point \#4 in Figure 1c). Each sample was abraded for $24 \mathrm{~h}$ in triplicates; error bars indicate \pm one standard deviation.

\subsection{Model of Sediment Transport and Sorting in Pigeon Cay}

The wave hydrodynamics and sediment transport model were used to understand how grains of different sizes move across the shore and predict the grain size distributions at different locations along the shore and along the transect. The model predicts the coarsest sediment at the beach, where almost all grains are greater than $250 \mu \mathrm{m}$ in diameter. The amount of grains in the coarse fraction $(1000 \mu \mathrm{m})$ decreased offshore, up to a depth of about $2 \mathrm{~m}$, but increased further offshore up to a depth of $4-5 \mathrm{~m}$. This prediction qualitatively matched the observed trend in grain size along the transect, even though the model overestimated the grain size at the shore.

The model reached a steady configuration in bed elevation and grain size distribution after about 100 years of evolution (Figure 7); however, the bed elevation and the grain size kept fluctuating at monthly time scales (Figure 8). As intuitively expected, temporal changes in grain size distribution were larger in the upper as opposed to the lower part of the shore profile. Based on morphokinematic arguments $[58,59]$, we operatively defined the upper shoreface as the area where the grain size changed by more than $1 \%$ from the initial distribution over a time span of 100 years, and the lower shoreface as the area where the grain size changed by less than $1 \%$ over the same period. Based on these defined areas, the transition between the two zones occurs at a distance of about $200 \mathrm{~m}$ from the shore. The water depth there is about $5 \mathrm{~m}$. 


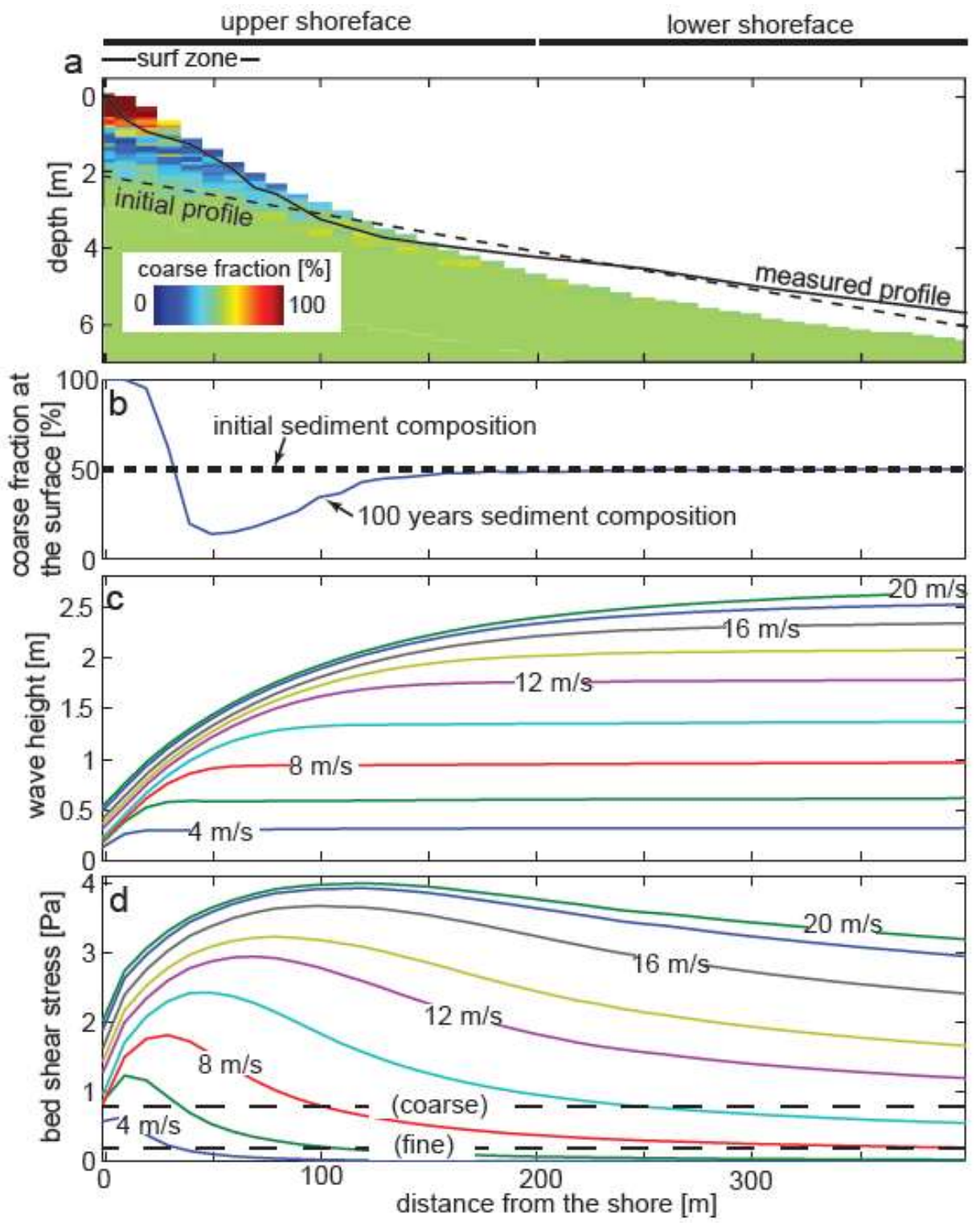

Figure 7. Predicted wave hydrodynamics and morpho-stratigraphy evolution at the Pigeon Cay transect. (a) Bed profile after 100 years of morphological evolution. Two classes of sediments were simulated $(250$ and $1000 \mu \mathrm{m})$; colors indicate the fraction of coarse material $(1000 \mu \mathrm{m})$. The limit of the surf zone is defined as the point where the water depth reaches $2.5 \mathrm{~m}$, and coincides with the point where waves generated by $12 \mathrm{~m} / \mathrm{s}$ winds break. (b) Fraction of coarse material at the bed surface. (c) Wave height for different wind speeds. (d) Bed shear stress for different wind speeds. Dashed lines indicate the critical shear stress for motion of a grain size of $250 \mu \mathrm{m}$, equal to $0.2 \mathrm{~Pa}$, and $1000 \mu \mathrm{m}$, equal to $0.8 \mathrm{~Pa}$. 


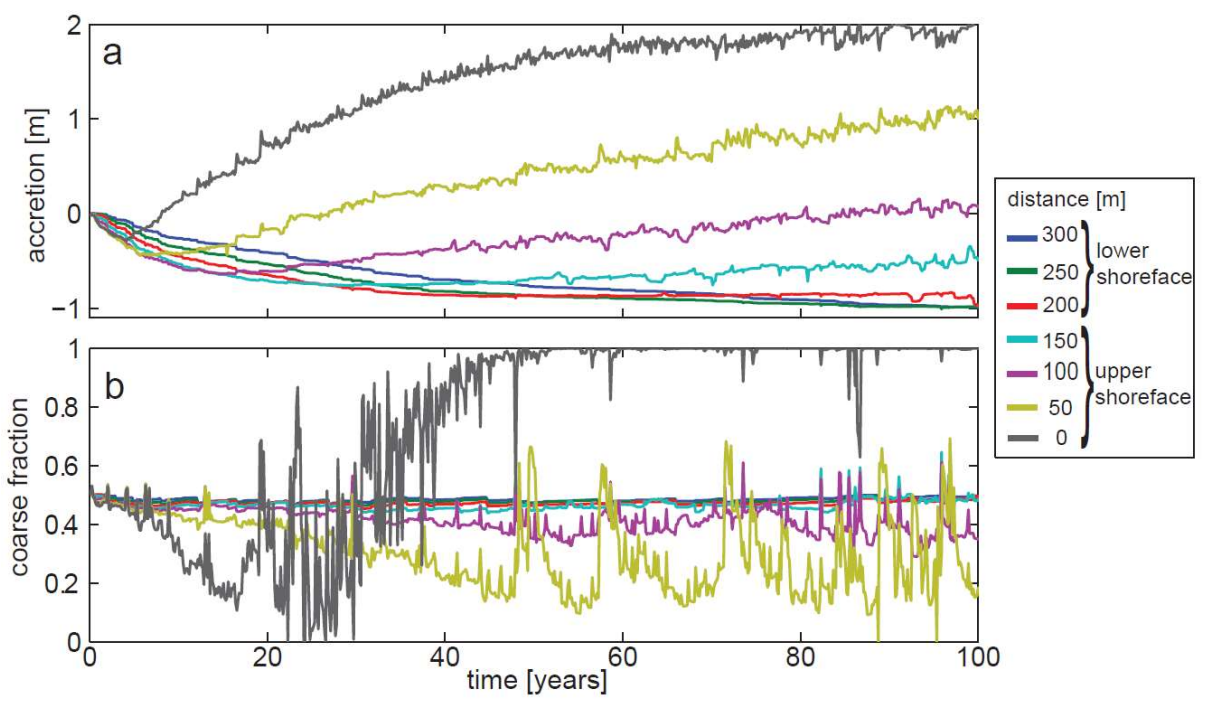

Figure 8. Results of the hydro-sedimentary model. Starting from the initial profile, changes in bed elevation (a) and grain size (b) are plotted over time at different locations along the modeled shore profile (see Figure 7). The bed elevation and size distribution reach a statistically steady state after about 100 years of morphological evolution. Fluctuations caused by variable wave conditions are present throughout.

The simple model for the age of the microbial mats was then used to determine areas in Pigeon Cay that are likely to be colonized by benthic microbes. Even though the rate of microbial growth is highly variable [60], we assumed that four weeks are needed for microbial colonization, following field observations that visible, mm-thick cyanobacterial communities can colonize a bed of unmoving grains in about a week [60], and that carbonate crusts on the surface of unmoving grains can form within a few months or less [36]. The model shows that mats older than four weeks could not develop in the surf zone within $50 \mathrm{~m}$ from the shore (Figure 9). In contrast, mats that are at least four weeks old are likely present outside the surf zone and should be present for $\sim 15$ days per year at a distance of $100 \mathrm{~m}$ from the shore, for $\sim 30$ days per year at a distance of $150 \mathrm{~m}$ from the shore, and $\sim 75$ days per year at a distance of $300 \mathrm{~m}$ from the shore (Figure 9).

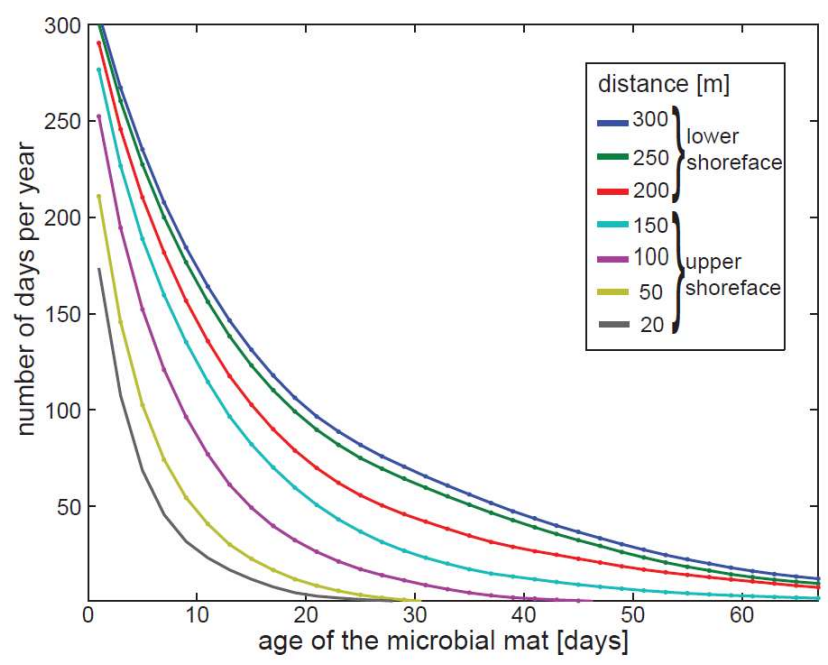

Figure 9. Frequency distribution of the age of microbial mats. The ages were computed using a simple model for microbial mat growth and destruction at different locations along the modeled shore profile (see Figure 7). 


\section{Discussion}

\subsection{Sedimentary Processes at Pigeon Cay}

At Pigeon Cay the surface bed grain size shows more variability within less than two hundred meters away from the shore than over several kilometers along the beach (Figure 2). Therefore, processes that influence the variability across the shore may be key to explaining the formation of ooids and grapestones. Morphological analysis of ooid grains also sheds light on the time scales of sediment transport. In agreement with previous observations [31], the degree of grain sphericity decreases and the aspect ratio increases with the increasing grain size (Figure 4a,b). Notably, this relationship between shape parameters and grain size does not depend on the location along the $150 \mathrm{~m}$ transect, i.e., a grain of a given size has the same sphericity and aspect ratio independently of where the grain is located along the transect. Thus, sediments across the shoreface are likely mixed across the shore fast relative to the timescale of processes that change the macroscopic shapes of the grains.

The sediment transport model gives another line of evidence for the time scales of cross-shore transport. The offshore fining of the grain sizes and the large temporal fluctuations of grain size indicate that the upper shoreface experiences a fast and effective grain sorting. This is in agreement with the short morphological time scale of the upper shoreface [61,62]. On the other hand, the offshore coarsening and the smaller fluctuation in grain size $(<10 \%$ of the average value) in the lower shoreface indicate a less effective grain sorting in this region. Indeed the large grain size predicted for the lower shoreface is not caused by active sorting, but rather by the inability to transport these large grains toward the surf zone. Thus, the offshore coarsening at Pigeon Cay indicates the presence of a mechanism that increases grain size in situ.

Here we suggest that benthic, microbially induced carbonate precipitation can directly increase the grain size and merge grains into grapestones. Microbes are well known to promote carbonate precipitation and foster accretion of structures such as stromatolites $[60,63,64]$. The presence of surficial, mm-thick microbial mats just outside the surf zone was documented by field observations [38] and is also consistent with the modeled frequency of bed reworking and bed age in this area (Figure 9). Importantly, microbial mats can be present at about $100 \mathrm{~m}$ from the shore (Figures $2 \mathrm{c}$ and 9), where the bed is not reworked too often to prevent any colonization, but the wave energy is still large enough to mobilize and transport grains to the surf zone once in a while.

Microbial mats were absent from the surf zone during our survey. This observation is consistent with the modeling prediction (Figure 9). The surf zone stands out as an area of grain abrasion. Our laboratory experiments found high rates of ooid abrasion, in accordance with previous studies $[8,65]$. These values correspond to a decrease in equivalent radius of about $0.03 \mu \mathrm{m}$ per day for the polished ooids and about $0.2 \mu \mathrm{m}$ per day for the grapestones and dull ooids, indicating that small surface irregularities on ooids can be abraded within days once ooids are mobilized.

Both modeling results and observations indicate that the hydrodynamic conditions in Pigeon Cay allow for multiple cycles of microbial colonization of ooids, and subsequent mobilization of ooids over the course of one year to decades. Even though the model cannot track individual grains, temporal fluctuations of the grain size distribution (Figure 8) suggest that individual grains might travel back and forth along the upper shoreface at monthly to annual time scales. These time scales are also consistent with the radiometric ages of ooid carbonate; for 1000-year-old ooids [39] that are $400 \mu \mathrm{m}$ in diameter, and with $2 \mu \mathrm{m}$ thick laminae [1], an accretion cycle that produces each lamina would take about 10 years. If so, the same grain would spend some of this time in the frequently reworked surf zone, where microbial mats are absent, and some time residing outside the surf zone, where microbial mats form and where sediments are mobilized only by large waves.

Support for this ooid cycle comes from the observation that up to $40 \%$ of the grains at about $100 \mathrm{~m}$ from the shore-where microbial mats are present-are comprised of ooids (Figures 2, 3C and 4). The sizes and shapes of ooids from the microbially colonized areas are the same as those ooids found in the surf zone (Figure 3a,b), but the offshore ooids are characterized by a dull appearance due to the 
accretion of microcrystalline $\mathrm{CaCO}_{3}$ on the surface (Figure 5b). These ooids are analogous to the dull, coated and encrusted ooids reported from quiet areas of Laguna Madre, Texas [66], and in stabilized tidal shoals of Eleuthera Bank, The Bahamas [36].

\subsection{A Conceptual Model for Ooid Growth: The Conveyor-Belt}

The observations from Pigeon Cay invoke a conveyor belt model for ooid growth at this location. This conceptual model can account for the composition and abundance of organic matter bound within ooid cortices, and for the distribution and morphology of carbonate grains in different areas of Pigeon Cay. The model is based on the observations that waves are the major resuspension agent at the site. The cycle of ooid growth starts with large waves that suspend sediments, move them outside the surf zone and deposit them on the top of the seafloor. An interval without wave activity diminishes the loss of carbonate by abrasion and facilitates microbial colonization and carbonate precipitation, forming dull grains (Figure $5 b$ ). During this time ooids acquire their biosignatures. Waves then rework the top layer, erode microbial mats/incipient carbonate crusts and abrade ooids. Some ooids are transported back to the surf zone, where they are further abraded and polished. Erosion experiments suggest that the polishing may occur within days (Figure 5a), even though the already polished ooids lose less mass per unit time, possibly because of the absence of irregularities around grains (Figure $5 \mathrm{~d}, \mathrm{e}$ ). In addition to this cross-shore random transport, physical sorting tends to concentrate large ooids in higher energy areas, i.e., at the top of the shoreface. This mechanism accounts for the observed relationships between environmental energy and ooid size [1,18] (Figure 2).

Particles further offshore require longer times to be transported back onshore. This time increases even more for larger particles because their mobilization requires larger, less frequent waves (Figure 7d). The longer a grain rests in the microbially colonized areas outside the surf zone, the more likely it is to merge with an adjacent grain to form a grapestone. This merging leads to a sudden increase in grain size and further decreases grain mobility. Small ooids from the same areas where grapestones form can be mobilized often enough to prevent merging and thus remain in the conveyor belt (Figure 10). This sorting model explains the seaward coarsening outside the surf zone in Pigeon Cay, a trend that contrasts the seaward fining that generally characterizes high energy siliciclastic shores [67].

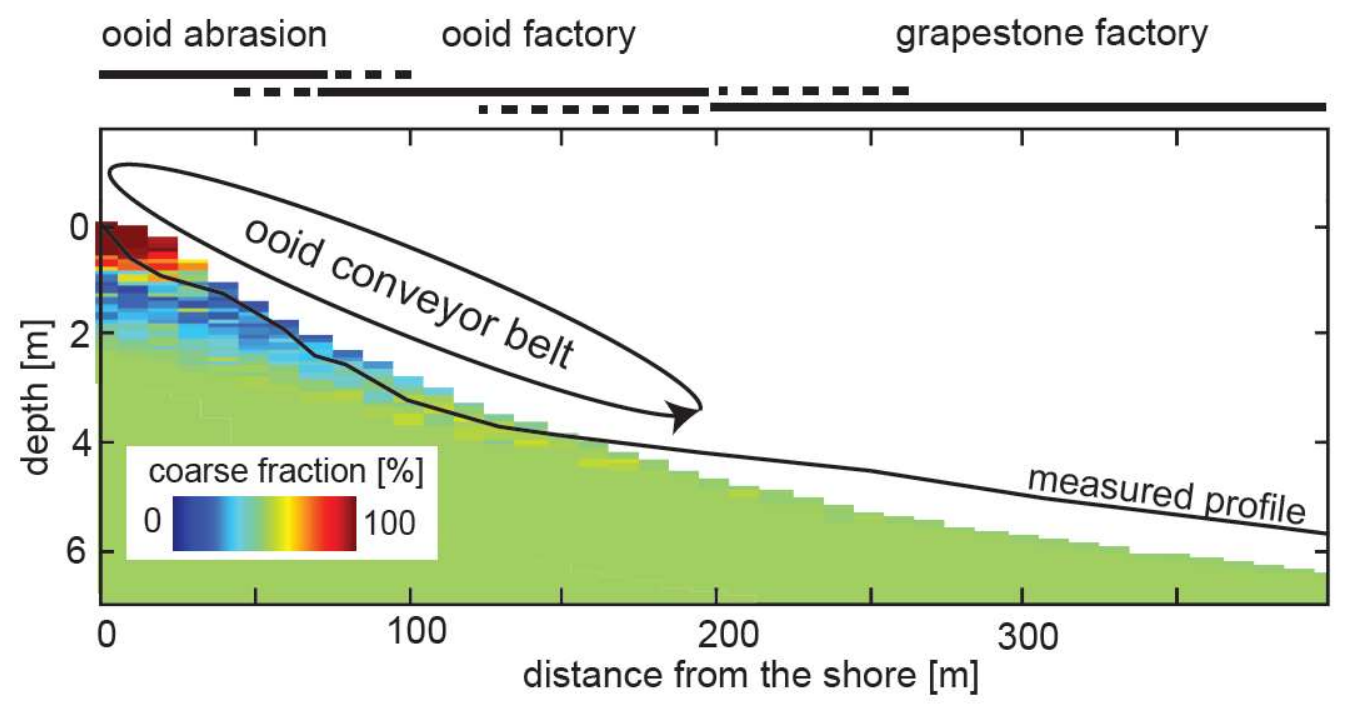

Figure 10. Conceptual model for the formation of ooid and grapestones. The ooid factory, where much ooid accretion occurs, is located in the upper shoreface, but outside the surf zone. Benthic microbial communities grow in these sediments, but are intermittently destroyed by high-energy events. Physical processes transport ooids in and out of the surf zone, where ooids are sorted, abraded and polished. The grapestone factory is located in the lower shoreface, and it overlaps with the ooid factory. 
The conveyor belt model of ooid formation assumes that, while at rest, ooids accrete a thin layer of carbonate without merging with other grains. This assumption is consistent with the report of the fibrous, continuous, isopachous aragonite cement found around grains in recently stabilized tidal shoals in The Bahamas [36]. Similar cement can be seen on the ooids from the area outside the surf zone in Pigeon Cay, and this can explain their dull and encrusted appearance (Figure 5b). The faster erosion rate of dull ooids (i.e., ooids from outside the surf zone) relative to originally polished ooids (i.e., the ooids from the surf zone) (Figure 6), suggests that any surface irregularities that form outside the surf zone can be removed quickly. However, dull ooids may not be completely abraded during this process. For example, a dull ooid transported to the surf zone would require about a day of erosion to become polished, but it would take about one month of continuous reworking to remove a $\mu \mathrm{m}$-thick lamina and reduce the ooid diameter by $2 \mu \mathrm{m}$.

Ooids accrete while in the conveyor belt and eventually become too large to be transported onshore, either because they acquire too many laminae or because they merge with other grains. The large grains exit the conveyor belt and remain trapped in the lower shoreface, which becomes an "ooid graveyard". The largest possible ooid size predicted by the conveyor belt model is the size of the largest grain that can be mobilized outside the surf zone often enough to prevent merging with other grains. This size is a function of the wave regime and the time required for grain merging. Specifically, the size of the particle that can remain in the conveyor belt increases with the energy of the waves that reach the shoreface. This predicts larger ooids on beaches exposed to higher wave energies and is consistent with the presence of largest grains on the beach at the headland of Pigeon Cay (Figure 1c), where the offshore slope is the steepest; waves converge and energy is higher than that along embayments and straight coasts [68].

\subsection{Biosignatures in Ooids}

A resting period within microbial mats provides a straightforward explanation for the presence of the same organic content and lipid biosignatures in both ooids and grapestones [38]. Specifically, ooids may trap organic matter during precipitation of carbonate within microbial mats [38].

The idea that ooids spend some time within microbial mats is also supported by a recent model of abiotic ooid growth, which suggests the need for a "stationary phase" during which ooids rest on the seafloor and are colonized by photosynthetic mats [7]. Based on isotopic analysis, however, these authors conclude that the stationary phase does not contribute to actual ooid growth or to the formation of biosignatures. Instead, these authors attribute biosignatures found in ooids to endolithic activity, a process not associated with the formation of new carbonate.

Endoliths are common in Bahamian ooids including those at Pigeon Cay and can indeed lead to micritization [69]. The organic signatures from ooids in Pigeon Cay, however, do not support the presence of a strong signal from the endolithic community. Fatty acids preserved in the cortices of all ooids show a strong benthic bacterial signal influenced by early diagenetic transformations that denote, and in fact require, reducing conditions [38]. This evidence for microbially-influenced reductions such as conversion of stenols to stanols within the ooids and the near absence of unsaturated fatty acids in the preserved lipids is remarkably similar across zones of contrasting hydrodynamic conditions and grain sizes [38]. Metagenomic data further indicate that reducing conditions and active sulfate reduction are much more prevalent outside of the surf zone [70], rather than in actively mobilized ooids.

The hypothesis that the organic signatures in ooids are not associated with endoliths is further supported by the ooids found in some sheltered shores of Hamelin Pool, Western Australia, a rimmed carbonate platform where microbially mediated carbonate precipitation promotes the formation of modern stromatolites [69]. These ooids have well-preserved cortices and are not extensively bored, and thus the carbonate-bound organic signatures of these ooids best reflect conditions when carbonate was precipitated [14]. In line with our prediction, the concentrations and compositions of fatty acids 
extracted from the carbonate-bound fraction of the ooids of Hamelin Pool were found to be similar to those isolated from the extensively bored Bahamian ooids [14,38].

\subsection{Petrographic Implications of Models for Suspended and Benthic Ooid Growth}

The conveyor belt model per se does not require the accretion of the ooid laminae within microbial mats: a conveyor belt can transport ooids from the areas where microbial mats grow to areas where the grains could accrete and abrade while in suspension. Both the suspension and benthic growth models are compatible with the hydrodynamics and sediment transport at the site, but the two processes should leave different petrographic fingerprints. Particular differences are expected in the thickness and regularity of ooid laminae and in the presence of multiple nuclei or encrusting organisms within the laminae.

The suspension growth model predicts an equilibrium size of ooids in which accretion balances abrasion [8,18], and requires that the thickness of the laminae decreases outward as the ooid asymptotically reaches the equilibrium size [9]. In contrast, the benthic growth mechanism in the conveyor belt model does not make predictions about trends in the thickness of the laminae. A study consistent with the suspension model reports an outward increase in the band density (i.e., a thinning of the laminae) in 200-300 $\mu \mathrm{m}$ diameter, radial and tangential ooids from the Jurassic Twin Creek Formation [71]. However, other ooids record different trends: the thicknesses of subsequent laminae remain nearly constant in tangential Recent Bahamian ooids [1,16] (Figure 11a) and in ooids from the Neoproterozoic Beck Spring Formation and the Cambrian Newfoundland Man o' War Member (Figure 11b,c), and actually increase outward in the well-preserved radial and tangential ooids of the Jurassic Smackover Formation [72].
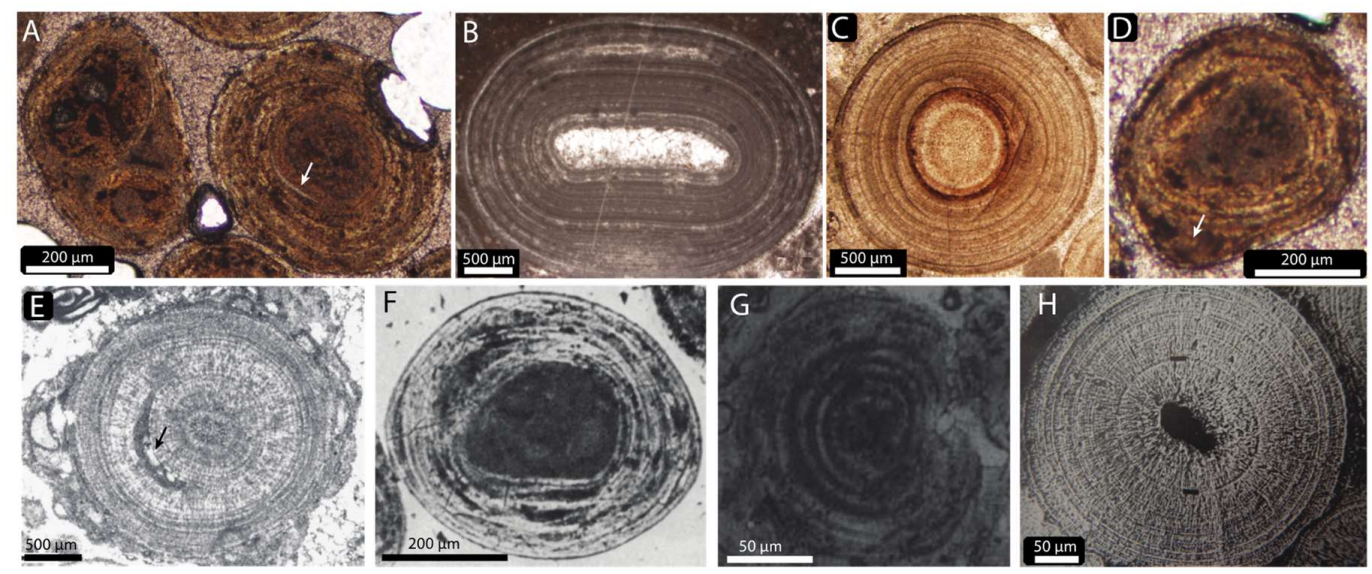

Figure 11. Examples of ooid petrography. (A) Large $(\sim 500 \mu \mathrm{m})$ ooids from the headland site of Pigeon Cay (Figure 1). Note the presence of multiple nuclei (on the left), irregular laminae (arrow), and the absence of outward thinning of successive laminae. (B,C) Neoproterozoic ooids from the Beck Spring Formation (B) and Cambrian ooids from the Man o' War Member of western Newfoundland (c), both showing successive laminae that do not thin outward. (D) Recent Bahamian ooid showing a lens-shape inclusion of unoriented aragonite. (E) Triassic ooid with encrusting foraminifera [73]. (F) Recent Bahamian ooid with irregular laminae [74]. (G) Benthic ooid from a modern hypersaline microbial mat showing regular laminae [75]. (H) Jurassic ooid showing regularity of individual laminae and outward thinning of successive laminae [71].

The geometric argument used to support the suspended growth mechanism attributes the exceptional regularity of individual laminae to inorganic suspended growth [76]. Indeed, laboratory experiments in which ooids inorganically precipitate in suspension create highly regular laminae $[5,77]$. On the other hand, several studies report ooids from the rock record with irregularly thick [78], wrinkled [78], arcuate [79], and crenulated laminae [80] (Figure 11f). Similar irregularities may point 
toward a benthic growth mechanism [80], with the caveat that the laminae of benthic ooids from hypersaline mats of Lanzarote [75], or those from the freshwater mats of Lake Geneva [81], are seemingly as regular as those of frequently abraded ooids (Figure 11g). Therefore, arguments that use the regularity of laminae in support of either hypothesis would require additional quantifications of the regularity of laminae in well-preserved ooids, and experimental tests that examine the regularity of laminae around ooids that experience alternating periods of benthic carbonate precipitation and abrasion.

Additional arguments in favor of benthic growth can be found in ooids that contain multiple nuclei or lens-shaped areas of unoriented aragonite [1] (Figure 11d) and foraminiferal encrustations in cortices [73,82,83] (Figure 11e). Growth in suspension requires that carbonate precipitates immediately around the surface of ooids that are in constant motion and contact other grains only during collisions. The impacts and abrasion make the merging of multiple nuclei and encrustation very unlikely in areas where ooids are mobilized. However, they are possible and expected if carbonate precipitation cements particles onto ooids on the seafloor, much like carbonate precipitation binds multiple ooids into grapestones. In contrast, carbonate precipitation in suspension may account for more laminae in the cortices of ooids with nuclei that do not contain merged grains or encrusted laminae, have extremely regular and outwardly thinning laminae (Figure 11h) and contain little organic matter. In both cases, laminae could form seasonally, e.g., related to temperature, or over multiple years, e.g., as a function of stochastic wave events.

These petrographic fingerprints - if opportunely quantified-could be used to evaluate the contributions of the two mechanisms to the growth of ooids. The presence of irregular laminae and multiple nuclei and the absence of outward laminae thinning in the ooids of Pigeon Cay (Figure 11a) suggest that benthic processes contribute, at least partly, to the growth of these ooids. Some Archean ooids also preserve evidence for the contribution of benthic processes in the form of off-center nuclei, wavy laminae or thicker laminae on one side of the ooids [78], composite ooids (grapestones), and the distribution of carbonaceous material and biogenic elements [84]. These ooids also do not appear to have outwardly thinning laminae. Further analysis is needed to determine whether benthic processes contributed to the growth of other ancient ooids, including those from the Archean and Proterozoic eons.

It should also be emphasized that both the benthic and suspension growth models assume that abrasion plays a fundamental role in the development of ooid geometry. As such, the benthic growth model does not contradict the conclusion that different modalities of sediment transport, i.e., suspended versus bedload, can lead to different ooid geometries [85].

\subsection{Conditions for Benthic Ooid Growth at Other Sites}

According to the benthic growth model, the time scales for carbonate accretion, microbial colonization/growth and the intensity and frequency distribution of sediment reworking events are critical parameters in ooid formation. The frequency of sediment reworking and the microbial colonization rate on Cat Island determine the landward limit of the area where ooid accretion occurs. The frequency and transport capacity of the largest wave event and the carbonate precipitation rates in the microbially-colonized sediments determine the seaward limit of where ooids can accrete without merging and becoming grapestones. These parameters seem to favor ooid formation on the west side of Cat Island, perhaps due to its unique wave conditions. Indeed, because of the mainly easterly wind, the west side of Cat Island does not experience sediment reworking for long periods, but the absence of a rim at the end of the shelf allows relatively large waves ( $>1 \mathrm{~m}$ high) to rework sediments during westerly winds. Other west-facing shores in The Bahamas are typically protected by rims and hence do not experience large sediment reworking during westerly winds.

The conceptual model of the ooid conveyor belt can also explain the origin of microbial signatures in other prominent ooid-bearing environments, including tidal shoals that are commonly found at the seaward edge of shallow carbonate platforms. There, molecular signatures of microbes are found in 
ooids from different locations, including active, non-active and mat-stabilized seafloors [10]. According to the model, tidal shoals should feature both frequently reworked locations, where ooids are abraded, as well as locations that are seldom reworked. Ooid carbonate can precipitate in microbially colonized areas and incorporate organic matter. Sites of grain erosion could be tidal channels and the crests of shoals, sand waves and megaripples. Conversely, sites conducive to temporary microbial growth may be present in the troughs of 10-1000 m large bedforms [18,86]: microbial mats capable of encrusting and cementing grains have been observed everywhere on tidal bars except on the frequently agitated crests [36]. Sediment transport between energetic crests and quieter troughs at the time scale of tides or wave events is plausible, and has been assumed in previous numerical models for ooid growth [9]. Verification of the conveyor belt hypothesis in tidal shoals and other environments requires quantification of sediment transport at the scale of shoals and macro-bedforms, as well as in situ surveys of microbially-colonized areas in space and time.

Previous models for ooid formation emphasized water chemistry as the key driver for ooid abundance through geologic time. The benthic growth model implies that ecology-specifically the presence of microbial mats and/or biofilms-is another critical factor. Field observations of the seafloor near Pigeon Cay revealed extensive cover by mm-thick microbial mats and a general scarcity of macroalgae. Similarly, microbial mats are abundant and grazers are scarce in Hamelin Pool, Western Australia, one of the few areas where both ooids and stromatolites are presently growing [17]. This observation from modern ooid-forming environments is consistent with a reduced animal and macroalgal abundance and a larger extent of areas colonized by microbes at other important intervals of Earth history characterized by abundant ooids, e.g., the Neoproterozoic, Cambrian, and Early Triassic [87-90]. A contribution of ecological factors to ooid formation throughout Earth history remains an intriguing and currently underexplored hypothesis.

\section{Conclusions}

Our analysis suggests that ooids in Pigeon Cay, Cat Island, The Bahamas, accrete in areas where the seafloor is devoid of animals and macroalgae. Microbial mats in these areas can grow over multiple weeks without sediment reworking but are reworked frequently enough to prevent the merging of small grains. Ooids are abraded and polished while residing in the high energy surf zone. Cross-shore sediment transport allows ooids to spend time in both the surf zone and the microbially colonized area. Larger, less mobile ooids have a higher chance of spending a longer time within microbial mats and merging with other grains. This process eventually forms grapestones that exit the ooid cycle.

The cycling of ooids to and from benthic environments is complementary to the model of ooid accretion by physicochemical precipitation in suspension and can better account for the presence of various lipid and molecular biosignatures in ooids, as well their lamina thickness and irregularity. Additional insights from the model require better quantitative constraints on sediment transport, temporal and spatial distribution of microbial mats and the rate of mineral precipitation inside microbial mats at other ooid-bearing sites. Laboratory experiments can also test whether temporary accretion of carbonate around ooids resting on the seafloor and in the presence or absence of microbial mats could create regular concentric laminae identical to those of marine ooids.

Author Contributions: Conceptualization, G.M., S.B.P. and T.B.; Formal Analysis, G.M.; Methodology, G.M., S.A.N. and S.B.P.; Software, G.M.; Resources, S.B.P., T.B., R.E.S.; Writing: Original Draft Preparation, G.M.; Writing: Review and Editing, G.M., S.B.P., R.E.S., T.B., S.A.N.

Funding: This research was supported by the National Aeronautics and Space Administration Astrobiology Institute (NNA13AA90A) Foundations of Complex Life, Evolution, Preservation, and Detection on Earth and Beyond. TB was supported by the Simons Foundation Early Career Investigator in Marine Microbial Ecology and Evolution. Acknowledgment is made to the Donors of the American Chemical Society Petroleum Research Fund for partial support of this research.

Conflicts of Interest: The authors declare no conflict of interest. 


\section{References}

1. Newell, N.D.; Purdy, E.G.; Imbrie, J. Bahamian oölitic sand. J. Geol. 1960, 68, 481-497. [CrossRef]

2. Heller, P.L.; Komar, P.D.; Pevear, D.R. Transport processes in ooid genesis. J. Sediment. Res. 1980, 50, $943-951$. [CrossRef]

3. Given, R.K.; Wilkinson, B.H. Kinetic control of morphology, composition, and mineralogy of abiotic sedimentary carbonates. J. Sediment. Res. 1985, 55, 109-119. [CrossRef]

4. Strasser, A. Ooids in Purbeck limestones (lowermost Cretaceous) of the Swiss and French Jura. Sedimentology 1986, 33, 711-727. [CrossRef]

5. Davies, P.J.; Bubela, B.; Ferguson, J. The formation of ooids. Sedimentology 1978, 25, 703-730. [CrossRef]

6. Ferguson, J.; Bubela, B.; Davies, P.J. Synthesis and possible mechanism of formation of radial carbonate ooids. Chem. Geol. 1978, 22, 285-308. [CrossRef]

7. Duguid, S.M.A.; Kyser, T.K.; James, N.P.; Rankey, E.C. Microbes and ooids. J. Sediment. Res. 2010, 80, $236-251$. [CrossRef]

8. Trower, E.J.; Lamb, M.P.; Fischer, W.W. Experimental evidence that ooid size reflects a dynamic equilibrium between rapid precipitation and abrasion rates. Earth Planet. Sci. Lett. 2017, 468, 112-118. [CrossRef]

9. Sumner, D.Y.; Grotzinger, J.P. Numerical modeling of ooid size and the problem of Neoproterozoic giant ooids. J. Sediment. Res. 1993, 63, 974-982.

10. Diaz, M.R.; Eberli, G.P.; Blackwelder, P.; Phillips, B.; Swart, P.K. Microbially mediated organomineralization in the formation of ooids. Geology 2017, 45, 771-774. [CrossRef]

11. Batchelor, M.T.; Burne, R.V.; Henry, B.I.; Li, F.; Paul, J. A biofilm and organomineralisation model for the growth and limiting size of ooids. Sci. Rep. 2018, 8, 559. [CrossRef] [PubMed]

12. Mitterer, R.M. Aminoacid composition of organic matrix in calcareous oolites. Science 1968, 162, 1498-1499. [CrossRef] [PubMed]

13. Mitterer, R.M. Biogeochemistry of aragonite mud and oolites. Geochim. Cosmochim. Acta 1972, 36, 1407-1422. [CrossRef]

14. Land, L.S.; Behrens, E.W.; Frishman, S.A. The ooids of Baffin Bay, Texas. J. Sediment. Res. 1979, 49, $1269-1277$. [CrossRef]

15. Reitner, J.; Arp, G.; Thiel, V.; Gautret, P.; Galling, U.; Michaelis, W. Organic matter in Great Salt Lake ooids (Utah, USA)—First approach to a formation via organic matrices. Facies 1997, 36, 210-219.

16. Folk, R.L.; Leo Lynch, F. Organic matter, putative nannobacteria and the formation of ooids and hardgrounds. Sedimentology 2001, 48, 215-229. [CrossRef]

17. Summons, R.E.; Bird, L.R.; Gillespie, A.L.; Pruss, S.B.; Roberts, M.; Sessions, A.L. Lipid biomarkers in ooids from different locations and ages: Evidence for a common bacterial flora. Geobiology 2013, 11, 420-436. [CrossRef] [PubMed]

18. Bathurst, R.G.C. Carbonate Sediments and Their Diagenesis. In Developments in Sedimentology; Elsevier: Amsterdam, The Netherlands, 1971; Volume 12.

19. Wanless, H.R.; Tedesco, L.P. Comparison of oolitic sand bodies generated by tidal vs. wind-wave agitation: Chapter 15. AAPG Spec. Vol. 1993, 48, 199-225.

20. Rankey, E.C.; Riegl, B.; Steffen, K. Form, function and feedbacks in a tidally dominated ooid shoal, Bahamas. Sedimentology 2006, 53, 1191-1210. [CrossRef]

21. Gebelein, C.D. Distribution, morphology, and accretion rate of recent subtidal algal stromatolites, Bermuda. J. Sediment. Res. 1969, 39, 49-69. [CrossRef]

22. Neumann, A.C.; Gebelein, C.D.; Scoffin, T.P. The composition, structure and erodability of subtidal mats, Abaco, Bahamas. J. Sediment. Res. 1970, 40, 274-297. [CrossRef]

23. Mariotti, G.; Perron, J.T.; Bosak, T. Feedbacks between flow, sediment motion and microbial growth on sand bars initiate and shape elongated stromatolite mounds. Earth Planet. Sci. Lett. 2014, 397, 93-100. [CrossRef]

24. Visscher, P.T.; Reid, R.P.; Bebout, B.M. Microscale observations of sulfate reduction: Correlation of microbial activity with lithified micritic laminae in modern marine stromatolites. Geology 2000, 28, 919-922. [CrossRef]

25. Camoin, G.F.; Montaggioni, L.F. High energy coralgal-stromatolite frameworks from Holocene reefs (Tahiti, French Polynesia). Sedimentology 1994, 41, 655-676. [CrossRef] 
26. Birgel, D.; Meister, P.; Lundberg, R.; Horath, T.D.; Bontognali, T.R.R.; Bahniuk, A.M.; de Rezende, C.E.; Vasconcelos, C.; McKenzie, J.A. Methanogenesis produces strong ${ }^{13} \mathrm{C}$ enrichment in stromatolites of Lagoa Salgada, Brazil: A modern analogue for Palaeo-/Neoproterozoic stromatolites? Geobiology 2015, 13, 245-266. [CrossRef] [PubMed]

27. Andres, M.S.; Sumner, D.Y.; Reid, R.P.; Swart, P.K. Isotopic fingerprints of microbial respiration in aragonite from Bahamian stromatolites. Geology 2006, 34, 973-976. [CrossRef]

28. Swart, P.K.; Reijmer, J.J.G.; Otto, R. A re-evaluation of facies on great Bahama Bank II: Variations in the $\delta^{13} \mathrm{C}, \delta^{18} \mathrm{O}$ and mineralogy of surface sediments. In Perspectives in Carbonate Geology; Swart, P.K., Eberli, G.P., McKenzie, J.A., Eds.; John Wiley \& Sons, Ltd.: Chichester, UK, 2009; pp. 47-59, ISBN 978-1-4443-1206-5.

29. Purdy, E. Recent calcium carbonate facies of the Great Bahama Bank. 2. Sedimentary facies. J. Geol. 1963, 71, 472-497. [CrossRef]

30. Winland, H.D.; Matthews, R.K. Origin and significance of grapestone, Bahama Islands. J. Sediment. Res. 1974, 44, 921-927.

31. Fabricius, F.H. Origin of Marine Ooids and Grapestones. In Contribution to Sedimentology; Schweizerbart: Stuttgart, Germany, 1977, ISBN 978-3-510-57007-2.

32. Gaffey, S.J. Formation and infilling of pits in marine ooid surfaces. J. Sediment. Res. 1983, 53, 193-208.

33. Tucker, M.E.; Wright, P. Carbonate Sedimentology; Wiley: Chichester, UK, 1990, ISBN 978-0-632-01472-9.

34. Haq, B.U.; Boersma, A. Introduction to Marine Micropaleontology; Elsevier Science: Amsterdam, The Netherlands, 1998, ISBN 978-0-444-82672-5.

35. Bathurst, R.G.C. Oölitic films on low energy carbonate sand grains, Bimini Lagoon, Bahamas. Mar. Geol. 1967, 5, 89-109. [CrossRef]

36. Dravis, J. Rapid and widespread generation of recent oolitic hardgrounds on a high energy Bahamian platform, Eleuthera Bank, Bahamas. J. Sediment. Res. 1979, 49, 195-207. [CrossRef]

37. Husinec, A.; Read, J.F. Transgressive oversized radial ooid facies in the Late Jurassic Adriatic Platform interior: Low-energy precipitates from highly supersaturated hypersaline waters. GSA Bull. 2006, 118, 550-556. [CrossRef]

38. O'Reilly, S.S.; Mariotti, G.; Winter, A.R.; Newman, S.A.; Matys, E.D.; McDermott, F.; Pruss, S.B.; Bosak, T.; Summons, R.E.; Klepac-Ceraj, V. Molecular biosignatures reveal common benthic microbial sources of organic matter in ooids and grapestones from Pigeon Cay, The Bahamas. Geobiology 2016, 1-19. [CrossRef] [PubMed]

39. Beaupré, S.R.; Roberts, M.L.; Burton, J.R.; Summons, R.E. Rapid, high-resolution ${ }^{14}$ C chronology of ooids. Geochim. Cosmochim. Acta 2015, 159, 126-138. [CrossRef]

40. Dominguez, L.L.; Mullins, H.T.; Hine, A.C. Cat Island platform, Bahamas: An incipiently drowned Holocene carbonate shelf. Sedimentology 1988, 35, 805-819. [CrossRef]

41. Rankey, E.C. Contrasts between wave- and tide-dominated oolitic systems: Holocene of Crooked-Acklins Platform, southern Bahamas. Facies 2013, 60, 405-428. [CrossRef]

42. Blott, S.J.; Pye, K. Gradistat: A grain size distribution and statistics package for the analysis of unconsolidated sediments. Earth Surf. Process. Landf. 2001, 26, 1237-1248. [CrossRef]

43. Francus, P. An image-analysis technique to measure grain-size variation in thin sections of soft clastic sediments. Sediment. Geol. 1998, 121, 289-298. [CrossRef]

44. Wadell, H. Volume, shape, and roundness of rock particles. J. Geol. 1932, 40, 443-451. [CrossRef]

45. Lesser, G.R.; Roelvink, J.A.; van Kester, J.A.T.M.; Stelling, G.S. Development and validation of a three-dimensional morphological model. Coast. Eng. 2004, 51, 883-915. [CrossRef]

46. Soulsby, R.L. Dynamics of Marine Sands; Thomas Telford Publishing: London, UK, 1997.

47. Herterich, K.; Hasselmann, K. The horizontal diffusion of tracers by surface waves. J. Phys. Oceanogr. 1982, 12, 704-711. [CrossRef]

48. Booij, N.; Ris, R.C.; Holthuijsen, L.H. A third-generation wave model for coastal regions-1. Model description and validation. J. Geophys. Res. Oceans 1999, 104, 7649-7666. [CrossRef]

49. Cavaleri, L.; Rizzoli, P.M. Wind wave prediction in shallow water: Theory and applications. J. Geophys. Res. Oceans 1981, 86, 10961-10973. [CrossRef]

50. Komen, G.J.; Hasselmann, K.; Hasselmann, K. On the existence of a fully developed wind-sea spectrum. J. Phys. Oceanogr. 1984, 14, 1271-1285. [CrossRef]

51. Collins, J.I. Prediction of shallow-water spectra. J. Geophys. Res. 1972, 77, 2693-2707. [CrossRef] 
52. Battjes, J.A.; Janssen, J.P.F.M. Energy loss and set-up due to breaking of random waves. Coast. Eng. Proc. 2011, 1, 569-587. [CrossRef]

53. Hasselmann, S.; Hasselmann, K. Computations and parameterizations of the nonlinear energy transfer in a gravity-wave spectrum. Part I: A new method for efficient computations of the exact nonlinear transfer integral. J. Phys. Oceanogr. 1985, 15, 1369-1377. [CrossRef]

54. Bijker, E.W. Some Considerations about Scales for Coastal Models with Movable Bed; Delft Hydraulics Laboratory: Delft, The Netherlands, 1967.

55. Bailard, J.A. An energetics total load sediment transport model for a plane sloping beach. J. Geophys. Res. Oceans 1981, 86, 10938-10954. [CrossRef]

56. Roelvink, J.A. Coastal morphodynamic evolution techniques. Coast. Eng. 2006, 53, 277-287. [CrossRef]

57. Mariotti, G.; Fagherazzi, S. Modeling the effect of tides and waves on benthic biofilms. J. Geophys. Res. Biogeosci. 2012, 117, 1-14. [CrossRef]

58. Cowell, P.J.; Stive, M.J.F.; Niedoroda, A.W.; de Vriend, H.J.; Swift, D.J.P.; Kaminsky, G.M.; Capobianco, M. The coastal-tract (Part 1): A conceptual approach to aggregated modeling of low-order coastal change. J. Coast. Res. 2003, 19, 812-827.

59. Stive, M.J.F.; de Vriend, H.J. Modelling shoreface profile evolution. Mar. Geol. 1995, 126, 235-248. [CrossRef]

60. Paterson, D.M.; Aspden, R.J.; Visscher, P.T.; Consalvey, M.; Andres, M.S.; Decho, A.W.; Stolz, J.; Reid, R.P. Light-dependant biostabilisation of sediments by stromatolite assemblages. PLoS ONE 2008, 3, e3176. [CrossRef] [PubMed]

61. Ortiz, A.C.; Ashton, A.D. Exploring shoreface dynamics and a mechanistic explanation for a morphodynamic depth of closure. J. Geophys. Res. Earth Surf. 2016, 121, 442-464. [CrossRef]

62. Larson, M.; Kraus, N.C. Prediction of cross-shore sediment transport at different spatial and temporal scales. Mar. Geol. 1995, 126, 111-127. [CrossRef]

63. Reid, D.R.P.; Macintyre, D.I.G.; Browne, D.K.M.; Steneck, D.R.S.; Miller, D.T. Modern marine stromatolites in the Exuma Cays, Bahamas: Uncommonly common. Facies 1995, 33, 1-17. [CrossRef]

64. Reid, R.P.; Visscher, P.T.; Decho, A.W.; Stolz, J.F.; Bebout, B.M.; Dupraz, C.; Macintyre, I.G.; Paerl, H.W.; Pinckney, J.L.; Prufert-Bebout, L.; et al. The role of microbes in accretion, lamination and early lithification of modern marine stromatolites. Nature 2000, 406, 989-992. [CrossRef] [PubMed]

65. Van Ee, N.J.; Wanless, H.R. Ooids and grapestone-A significant source of mud on Caicos platform. In Developing Models and Analogs for Isolated Carbonate Platforms-Holocene and Pleistocene Carbonate s of Caicos Platform, British West Indies; Morgan, W.A., Harris, P.M., Eds.; SEPM Society for Sedimentary Geology: Broken Arrow, OK, USA, 2008; pp. 121-125.

66. Freeman, T. Quiet water oolites from Laguna Madre, Texas. J. Sediment. Res. 1962, 32, 475-483. [CrossRef]

67. Komar, P.D. Beach Processes and Sedimentation; Prentice-Hall: Upper Saddle River, NJ, USA, 1976, ISBN 978-0-13-072595-0.

68. Woodroffe, C.D. Coasts: Form, Process and Evolution; Cambridge University Press: Cambridge, UK, 2002, ISBN 978-0-521-01183-9.

69. Harris, P.M.; Halley, R.B.; Lukas, K.J. Endolith microborings and their preservation in Holocene-Pleistocene (Bahama-Florida) ooids. Geology 1979, 7, 216-220. [CrossRef]

70. Diaz, M.R.; Norstrand, J.D.; Eberli, G.P.; Piggot, A.M.; Zhou, J.; Klaus, J.S. Functional gene diversity of oolitic sands from Great Bahama Bank. Geobiology 2014, 12, 231-249. [CrossRef] [PubMed]

71. Medwedeff, D.A.; Wilkinson, B.H. Cortical fabrics in calcite and aragonite ooids. In Coated Grains; Peryt, D.T.M., Ed.; Springer: Berlin/Heidelberg, Germany, 1983; pp. 109-115, ISBN 978-3-642-68871-3.

72. Wilkinson, B.H.; Buczynski, C.; Owen, R.M. Chemical control of carbonate phases; implications from Upper Pennsylvanian calcite-aragonite ooids of southeastern Kansas. J. Sediment. Res. 1984, 54, 932-947. [CrossRef]

73. Flügel, E. Microfacies of Carbonate Rocks; Springer: Berlin/Heidelberg, Germany, 2004, ISBN 978-3-662-08728-2.

74. Simone, L. Ooids: A review. Earth-Sci. Rev. 1980, 16, 319-355. [CrossRef]

75. Gerdes, G.; Dunajtschik-Piewak, K.; Riege, H.; Taher, A.G.; Krumbein, W.E.; Reineck, H.-E. Structural diversity of biogenic carbonate particles in microbial mats. Sedimentology 1994, 41, 1273-1294. [CrossRef]

76. Cayeux, L. Les Roches Sédimentaires de France. Roches Carbonatées; Impr. Nationale: Paris, France, 1929.

77. Li, S.; Wang, Z.J.; Chang, T.-T. Temperature oscillation modulated self-assembly of periodic concentric layered magnesium carbonate microparticles. PLoS ONE 2014, 9, e88648. [CrossRef] [PubMed] 
78. Beukes, N.J. Ooids and Oolites of the Proterophytic Boomplaas Formation, Transvaal Supergroup, Griqualand West, South Africa. In Coated Grains; Peryt, D.T.M., Ed.; Springer: Berlin/Heidelberg, Germany, 1983; pp. 199-214, ISBN 978-3-642-68871-3.

79. Swett, K.; Knoll, A.H. Marine pisolites from Upper Proterozoic carbonates of East Greenland and Spitsbergen. Sedimentology 1989, 36, 75-93. [CrossRef] [PubMed]

80. Swirydczuk, K.; Wilkinson, B.H.; Smith, G.R. The Pliocene Glenns Ferry Oolite: Lake-margin carbonate deposition in the Southwestern Snake River Plain. J. Sediment. Petrol. 1979, 49, 995-1004.

81. Davaud, E.; Girardclos, S. Recent freshwater ooids and oncoids from Western Lake Geneva (Switzerland): Indications of a common organically mediated origin. J. Sediment. Res. 2001, 71, 423-429. [CrossRef]

82. Talbot, M.R. Foraminiferid-encrusted ooids: Evidence for ancient subtidal algal mats? Geol. Mag. 1974, 111, 297-302. [CrossRef]

83. Wilson, R.C.L. Carbonate facies variation within the Osmington Oolite series in Southern England. Palaeogeogr. Palaeoclimatol. Palaeoecol. 1968, 4, 89-123. [CrossRef]

84. Siahi, M.; Hoffman, A.; Master, S.; Mueller, C.W.; Gerdes, A. Carbonate ooids of the mesoarchean pongola group, South Africa. Geobiology 2017, 15, 750-766. [CrossRef] [PubMed]

85. Sipos, A.A.; Domokos, G.; Jerolmack, D.J. Shape evolution of ooids: A geometric model. Sci. Rep. 2018, 8, 1758. [CrossRef] [PubMed]

86. Diaz, M.R.; Piggot, A.M.; Eberli, G.P.; Klaus, J.S. Bacterial community of oolitic carbonate sediments of the Bahamas Archipelago. Mar. Ecol. Prog. Ser. 2013, 485, 9-24. [CrossRef]

87. Hine, A.C. Lily Bank, Bahamas; history of an active oolite sand shoal. J. Sediment. Res. 1977, 47, $1554-1581$. [CrossRef]

88. Wilkinson, B.H.; Owen, R.M.; Carroll, A.R. Submarine hydrothermal weathering, global eustasy, and carbonate polymorphism in Phanerozoic marine oolites. J. Sediment. Res. 1985, 55, 171-183. [CrossRef]

89. Lehrmann, D.J.; Minzoni, M.; Li, X.; Yu, M.; Payne, J.L.; Kelley, B.M.; Schaal, E.K.; Enos, P. Lower triassic oolites of the Nanpanjiang Basin, South China: Facies architecture, giant ooids, and diagenesis-implications for hydrocarbon reservoirs. Aapg Bull. 2012, 96, 1389-1414. [CrossRef]

90. Woods, A.D. Microbial ooids and cortoids from the Lower Triassic (Spathian) Virgin Limestone, Nevada, USA: Evidence for an Early Triassic microbial bloom in shallow depositional environments. Glob. Planet. Chang. 2013, 105, 91-101. [CrossRef]

(C) 2018 by the authors. Licensee MDPI, Basel, Switzerland. This article is an open access article distributed under the terms and conditions of the Creative Commons Attribution (CC BY) license (http:// creativecommons.org/licenses/by/4.0/). 